\author{
Прогній П.Б. ${ }^{1}$, Попович Д.П. ${ }^{2}$, Захарчук О.П. ${ }^{1}$, Шевчук О.С. ${ }^{1}$, Попович П.В. ${ }^{1}$, Матвєєва I.В. ${ }^{3}$ \\ Островерхов В.М. ${ }^{1}$, Коцур А.С. ${ }^{1}$ \\ ${ }^{1}$ Західноукраӥнський національний університет, Тернопіль, Украӥна; ${ }^{2}$ Тернопільський \\ національний медичний університет імені І.Я. Горбачвського; ${ }^{3}$ Національний авіаційний \\ університет, Киів, Україна
}

\title{
БЕЗПЕКА ПЕРЕВЕЗЕНЬ ПАСАЖИРІВ У ГРОМАДСЬКОМУ ТРАНСПОРТІ В УМОВАХ ПАНДЕМІї
}

\begin{abstract}
В умовах пандемії COVID-19 виникають значні об’єктивні проблеми 3 точки зору безпечного перевезення населення громадським транспортом. Динамічна політика швидкого реагування при транспортуванні людей для зменшення ризиків зараження пасажирів і водіїв забезпечується тим, що при перевезеннях необхідним $є$ надання дозволу муніципальними органами влади на перевезення людей без обтяжуючих зайвих обмежень щодо числа пасажирів у салоні, дотримуватись рівня заповнення салону автобуса винятково відповідно до передбачених конструкцію транспортного засобу числа сидячих місць максимальної кількості пасажирів. Як доведено дослідженнями, штучне недовантаження транспортного засобу для уникнення щільного контакту пасажирів не впливає рівень зараження COVID-19, тому дане обмеження не є раціональним, спричиняючи недовантаження і нераціональні суттєві фінансові втрати перевізника, як наслідок, ймовірне звільнення найманих працівників, відповідно негативний соціальний ефект. Сформовано рекомендації, такі як, обов'язкове використання масок у комплекті з рукавичками, посилена вентиляція салону, а також організація посадки - висадки пасажирів тільки на задні двері та $100 \%$ безконтактна оплата проїзду для максимального захисту водія. Дане дослідження є основою формування політики перевезень пасажирів громадським транспортом 3 позиції визначення рівня безпеки в умовах COVID-19 та комфорту пасажирів з розробкою основ вимірювання сприйняття найважливіших факторів зручності громадського транспорту, мінімального дискомфорту і максимальної безпеки.

Ключові слова: організація перевезень, безпека пасажирів, громадський транспорт, пасажиропотік, маршрут
\end{abstract}

\section{ВСТУП}

Незважаючи на те, що зручність пасажирів та в час пандемії, безпека є базовими факторами попиту для громадського транспорту, а таким показником, як зручність в Україні завжди нехтується при проектуванні транспортних систем середніх містах, хоча вибір пасажирами громадського транспорту залежить від багатьох факторів. 3 метою збільшення рівня безпеки, а також зменшення рівня дискомфорту у громадському транспорті, транспортна послуга має проектуватися таким чином, щоб відповідність очікуванням пасажирів була максимально адекватною [1, 9]. На сьогодні, органами влади часто рекомендується при міських пасажирських перевезеннях дотримуватись заповнення салону автобуса лише відповідно до передбаченої конструкцією транспортного засобу максимальної кількості пасажирів для місць сидіння. Таке навантаження транспортного засобу для уникнення щільного контакту пасажирів позитивно впливатиме на навантаження металоконструкції та ходової частини, осей розширюючи зони комфортності коливання шин, збільшуючи ресурс роботи транспортних засобів [12-16].

\section{АНАЛІЗ ВІДОМИХ РЕЗУЛЬТАТІВ ДОСЛІДЖЕНЬ ТА ПОСТАНОВКА ПРОБЛЕМИ}

При міських перевезеннях громадським транспортом, зокрема у середніх містах за класифікацією ДБН Б.2.2-12:2019, в умовах пандемії COVID-19 виникають значні ускладнення 3 позиції оптимізації перевізних процесів за критерієм максимальної безпеки пасажирів та водіїв. За інформацією NACTO [1], органи управління транспортом у країнах світу перебувають на передових позиціях 3 точки зору реагування на пандемію шляхом раціональної розробки динамічної політики швидких дій при транспортуванні людей конкретно при даній надзвичайній ситуації. За дослідженнями групи китайських урядових епідеміологів, зокрема Hu Shixiong, the lead author of the study who works for the Hunan Provincial Centre for Diseases Control and Prevention, опублікованих ву Stephen Chen в "Practical Preventive Medicine" і South China Morning Post print edition від 9 березня, 2020 p. [2] встановлено, що SARS-CoV2 може перебувати у повітрі салону і на тих поверхнях транспортного засобу, на яких осіли дихальні краплі зараженої людини до кількох діб, значно підвищуючи ризик подальшої його передачі пасажирам транспортного засобу тактильним шляхом [2]. Тривалість часу перебування SARS-CoV2 на твердій поверхні залежить від таких факторів, як температура та тип поверхні, наприклад, при $37^{\circ} \mathrm{C}$, він може знаходитися протягом двох-трьох днів 
на склі, тканині, металі, пластику чи папері [2], що є великою проблемою. Необхідно сформувати політику міських перевезень населення громадським транспортом в умовах COVID-19 розробивши адекватні заходи для максимального уникнення розповсюдження COVID-19 при достатньому рівні показників комфорту з забезпеченням необхідних стратегій безпечного перевезення пасажирів у містах. Достатній рівень комфорту поїздки населення при використанні громадського транспорту при проектуванні транспортної мережі міста практично завжди нехтується, особливо при перевезеннях населення громадським транспортом у середніх міст, вважаючи, що такий показник, як час їздки буде єдиним показником який впливатиме на вибір пасажиром виду транспорту [9- 11, 19, 20, 21, 22$]$.

\section{ЦІЛЬ ТА ЗАДАЧІ ДОСЛІДЖЕННЯ}

Необхідно сформувати основу для проведення вимірювань суб'єктивного сприйняття пасажирами якості поїздки та запропоновано удосконалену політику міських перевезень населення громадським транспортом в умовах COVID-19 з оцінкою рівня дискомфорту у системі громадського транспорту середніх міст шляхом використання множини якісних і кількісних показників. Дослідженням забезпечується глибше розуміння суб'єктивного ставлення пасажирів до сприйняття якості транспортної послуги як фактору зручності при забезпеченні належного рівня безпеки з точки зору пандемії в послугах міського громадського транспорту. Важливо, що дані дослідження пасажиропотоків на автобусних маршрутах міського громадського транспорту в м. Тернопіль виконувалися як суцільні натурні дослідження табличним методом. Для здійснення аналізу досліджуються шість обертових рейсів на кожному діючому маршруті транспортної мережі міста у періоди: піковий ранковий - з 6.30- 10.00 год., міжпіковий - з 10.00 до 16.00 год., піковий вечірній - 3 16.00 до 19.30 год. Досліджуються особливості зміни пасажиропотоку по годинах доби, днях тижня, нерівномірність пересування пасажирів у часі і просторі по місту з початкової до кінцевої зупинки, а також оцінка основних пересадочні пункти міста, спосіб оплати за проїзд: готівковий чи безконтактний, пільговий. Період досліджень - 7 календарних днів, з 04.11.19 по 11.11.19 року, зміни пасажиропотоку вивчаються окремо у робочі і вихідні дні. Час проведення: 6.30 - 19.30 год. В салоні перебував один обліковець, працюючи у маршрутному транспортнному засобі починаючи з першої зупинки, розміщуючись за задніми дверима автобуса (рис. 1). Всі одержані дані по пасажирообігу і способу оплати, а також інформацію про вид транспорту, на якому проводяться дослідження, номер маршруту, напрямок руху транспортного засобу - прямий чи зворотній напрям, час початку i закінчення рейсу, час руху автобуса між зупинками, марку рухомого складу, обліковець самостійно, по факту записував у сформовану дослідниками картку обліку.

На території України налічується близько 66 міст [3, 4], які можна віднести до категорії середніх [3], площа міст з чисельністю мешканців від 50000 - 250000 чоловік становить до 65 квадратних кілометрів. Для такого міста, як Тернопіль, основним пасажиропотокам властиві діаметральні, або радіальні напрямки, щільність населення знаходиться в межах 113,1 чол./кв.км. За інформацією $[5,6,19,20,21,22]$, місто має 38 транспортних районів, загальна кількість автобусних маршрутів громадського транспорту становить 37, вони обслуговуються 197 од. автобусів, кількість зупиночних пунктів - 218 од., загальна довжина автобусної маршрутної мережі - 647, 7 км. Проведеними дослідженнями встановлено, автобусний парк громадського транспорту комплектується транспортними засобами малої пасажиромісткості типу “Богдан А092", “Еталон”, кожен з яких має місткість 42 пасажири. У пікові години по всій мережі громадського транспорту спостерігали перевантаження транспорту - коефіцієнт заповнення становив більше $100 \%$, причому середньодобовий коефіцієнт знаходився в межах 60-80\%.

Дослідженнями мережі громадського транспорту м. Тернополя, визначено основні базові показники мобільності пасажирів, які можуть бути характерними для середніх міст, що добре корелює $3[17,19,20,21,22]$, наприклад, моre than zero, fewer than 45, ideally 16: Those are the number of minutes that workers would prefer to spend commuting, according to various studies. Отже:

- швидкість притоку пасажирів на зупинку у між пікові періоди 1пас/хв, у години пік 4 пас/хв.;

- час очікування транспортного засобу до 10 хв.;

- час поїздки від периферійних районів до центру 30-35 хв. ;

- час поїздки між периферійними районами до 60 хв.;

- години пік ранкові 8.00-9.00 год., вечірні 16.30-18.30 год.;

- розрахункова швидкість переміщення пасажирів у автобусах міста 15-20 км/год.

\section{РЕЗУЛЬТАТИ ДОСЛІДЖЕННЯ}

Дослідження було проведено двома етапами робіт - камеральному, а також експериментальному - проведено збір та обробку даних, отриманих у результаті обстеження 
пасажирських потоків. Суцільні натурні дослідження табличним методом, який, в порівнянні 3 існуючими, є найбільш трудомістким, проте єдиним, який може забезпечити максимальну точність інформації про пасажирів для подальшої камеральної обробки отриманих статистичних даних досліджуваної системи автобусних маршрутів громадського транспорту м. Тернополя.

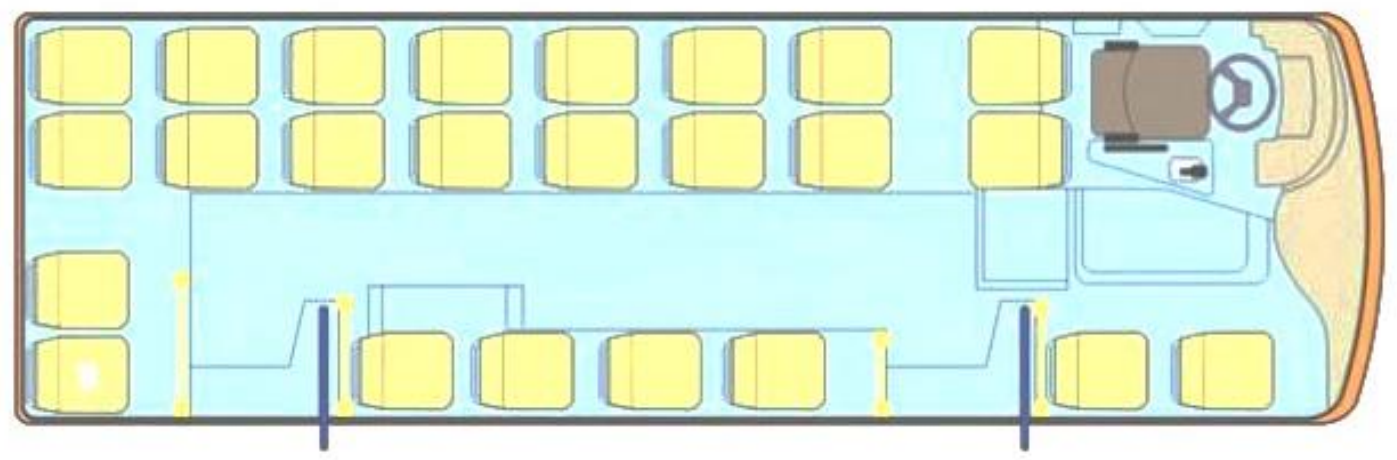

Рисунок 1. Розташування обліковця в салоні автобуса Богдан А092

Одержану органолептичним шляхом інформацію було внесено для подальшого опрацювання у сформовану спеціальну карту обліку, потім проводилися обчислення для ділянок руху між зупиночними пунктами кожного досліджуваного маршруту.

Проведеними дослідженнями встановлено, ступінь безконтактної (банківські картки, гугл пей) оплати за проїзд становив від $60 \%$ до $74 \%$ загального числа пасажирів, які оплачували проїзд, за винятком пільгових категорій населення, при пасажирських перевезеннях на маршрутах громадського транспорту у місті. Визначено, що час руху транспортного засобу між ділянками маршрутів, для всіх досліджуваних, знаходився у межах $2-2,3$ хвилини, в залежності від дорожньої обстановки, де межами ділянок є зупинки громадського транспорту. Мультикретеріальним аналізом транспортної мережі встановлено: коефіцієнт пересадочності пасажирів 1,1 ; коефіцієнт непрямолінійності 1,76 ; середній час очікування 5,8 хв.; маршрутний коефіцієнт 4,60; середній час пересування 33 хв.; середня відстань пересування 4,3 км., що корелює 3 даними, одержаними дещо раніше [5].

Оптимальним для формування політики міських перевезень населення громадським транспортом $[19,20,21,22]$ в умовах COVID-19 з позиції оптимізації за критерієм максимальної безпеки при раціональній завантаженості є застосування даних досліджень найскладнішого з позиції максимальної завантаженості маршруту (рис. 2) при перевезеннях населення міста за показниками найбільшої кількості пасажирів, відстані та часу перевезення, який лімітує одночасне перебування в закритому просторі - салоні маршрутного транспортного засобу людей. Для даного маршруту коефіцієнт непрямолінійності, середній час очікування, середній час пересування, середня відстань пересування $є$ вищими від вказаних вище середніх значень. Встановлено, що таким $є$ маршрут, що з'єднує два периферійні райони на діаметрально протилежних сторонах міста Тернопіль, №18. Довжина маршруту- 18,87 км., час виконання поїздки у одному напрямку -53 хв., час роботи- 36.20 год. по 20.50 год. 

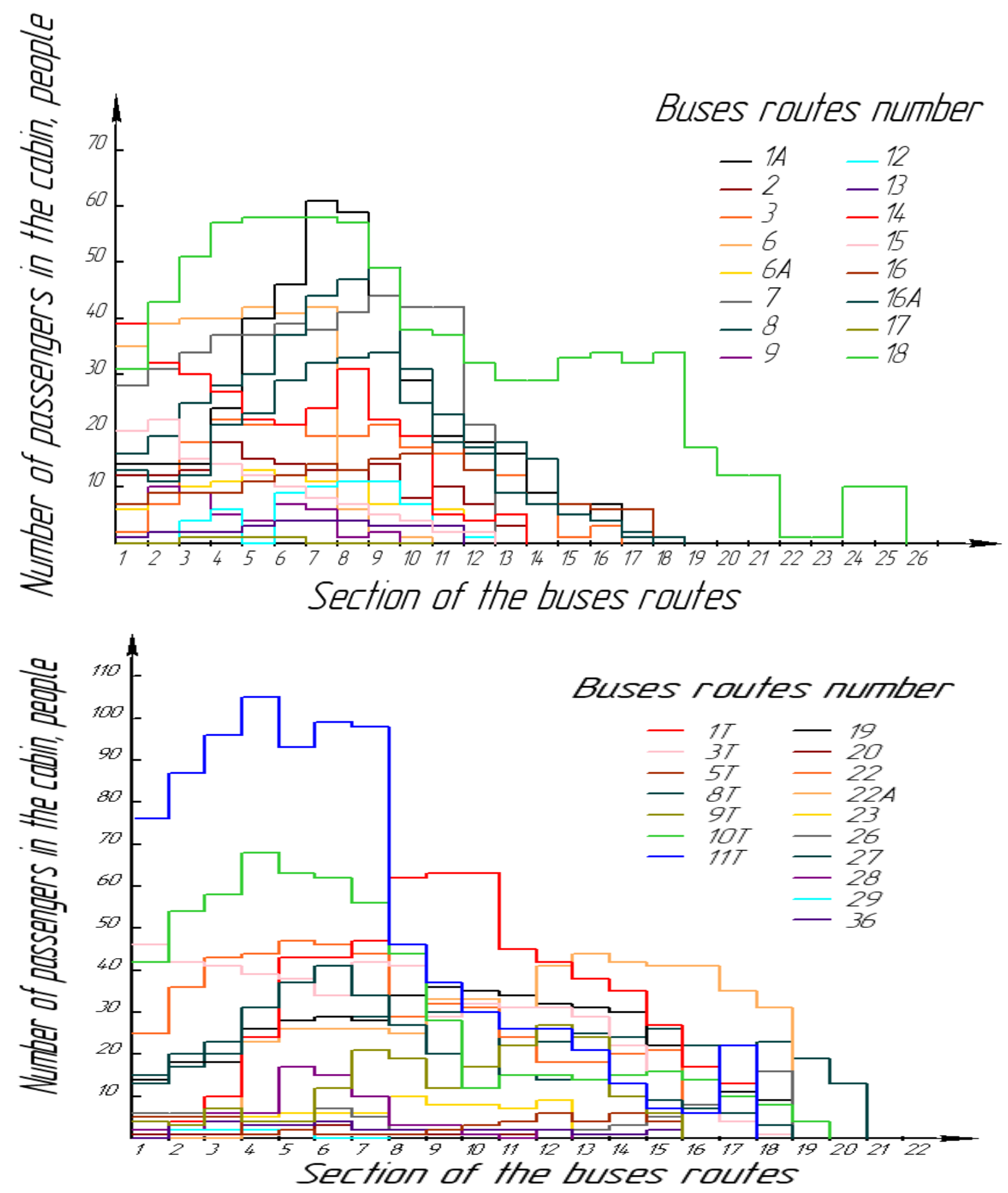

a) 

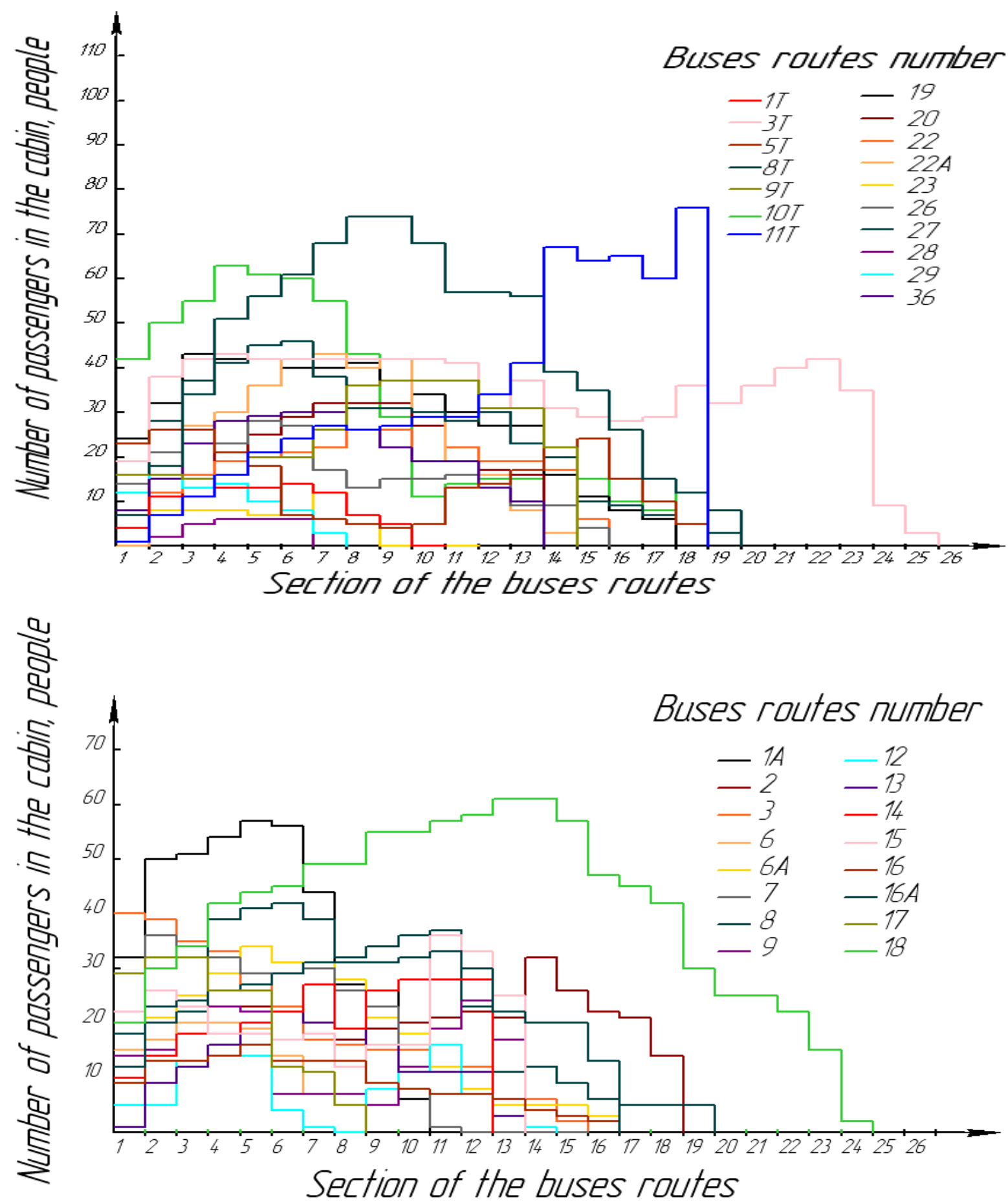

б)

Рисунок 2. Нерівномірність пасажиропотоку для вказаного транспортного засобу за ділянками маршруту

а) пряма поїздка; б) зворотня поїздка

Схему салону транспортного засобу - Богдан А092 пасажиромісткістю 42 місця, 3 яких для сидіння, включаючи водія, 25 місць, зображено на рис. 3 [7]. 


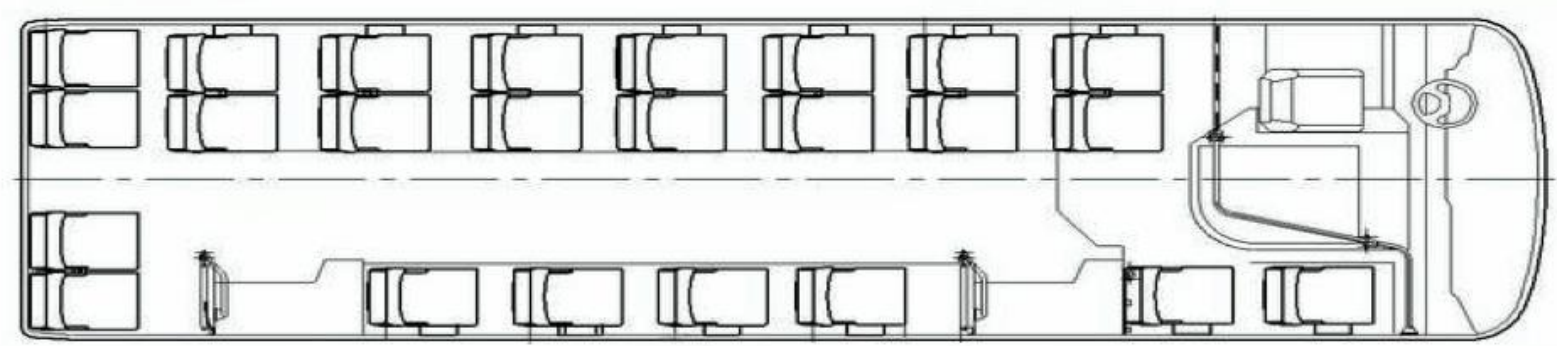

Рисунок 3. Салон автобуса малої vecicle capacity

В [9] функція рівня переповненості як функція дискомфорту розраховується з урахуванням пасажиромісткості транспортних засобів, враховуючи кількість місць для сидіння і тривалість поїздки. Розглядувалися різні варіанти поїздок, при першому вільних сидячих місць не було, при другому було одне місце для сидіння і при третьому варіанті пасажиромісткість транспортного засобу за рахунок великої кількості пасажирів використовувалася на 100\%. В роботі [10] запропоновано оцінювання переповненості шляхом вимірювання рівня переповненості за значенням коефіцієнта навантаження і кількості стоячих пасажирів на один квадратний метр, хоча часто такий показник нормований і враховується виробниками транспортних засобів ще на етапі проектування . При тому, що умовне порогове значення - одиниця буде перевищене, функція дискомфорту ростиме за експоненціальним законом [10]. Можливо, раціональним також буде апроксимувати закон зміни функції дискомфорту поліномом третього (четвертого) степеня моделюючи дану ситуацію.

ОБГОВОРЕННЯ РЕЗУЛЬТАТІВ ДОСЛІДЖЕНЬ

Для відображення сприйняття пасажирами рівня комфорту у громадському транспорті, в [11] моделюється лінійне підвищення рівня дискомфорту до порогового значення і при його перевищенні 3 наступним зростанням за експоненціальним законом. засобі [11]

Рівень дискомфорту, рис.4, є функцією розрахункової щільності пасажирів в транспортному

$$
x=\left\{\begin{array}{ccc}
\alpha & & \alpha \leq 1 \\
e^{\alpha} & \text { if } & \alpha>1
\end{array}\right.
$$

де рівень кількості пасажирів в транспортному засобі (х) обчислюється на основі показника $\alpha$

$$
\alpha=\frac{\text { Number of passengers in vecicle }}{\text { Vecicle capacity }}
$$




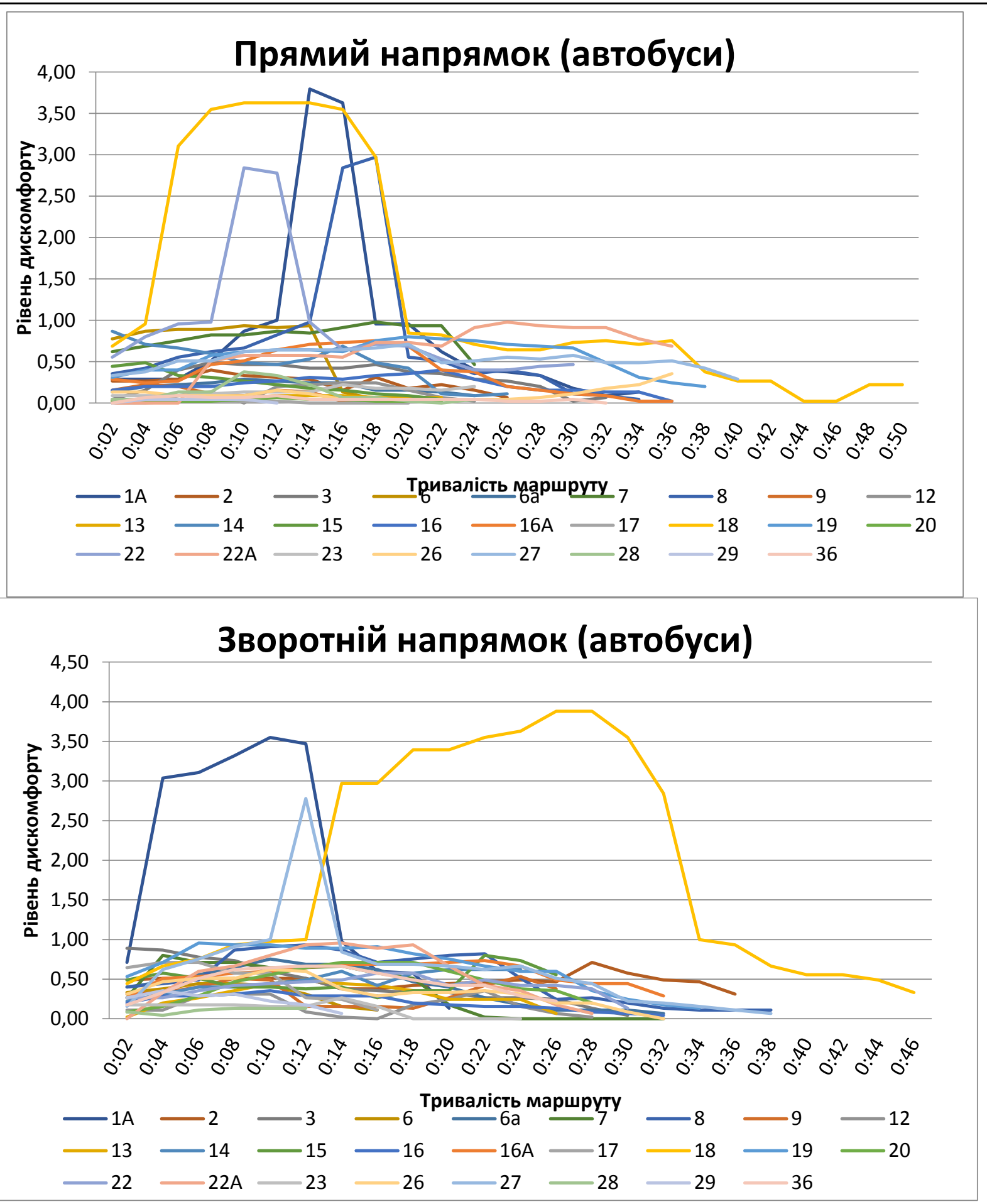

a) 

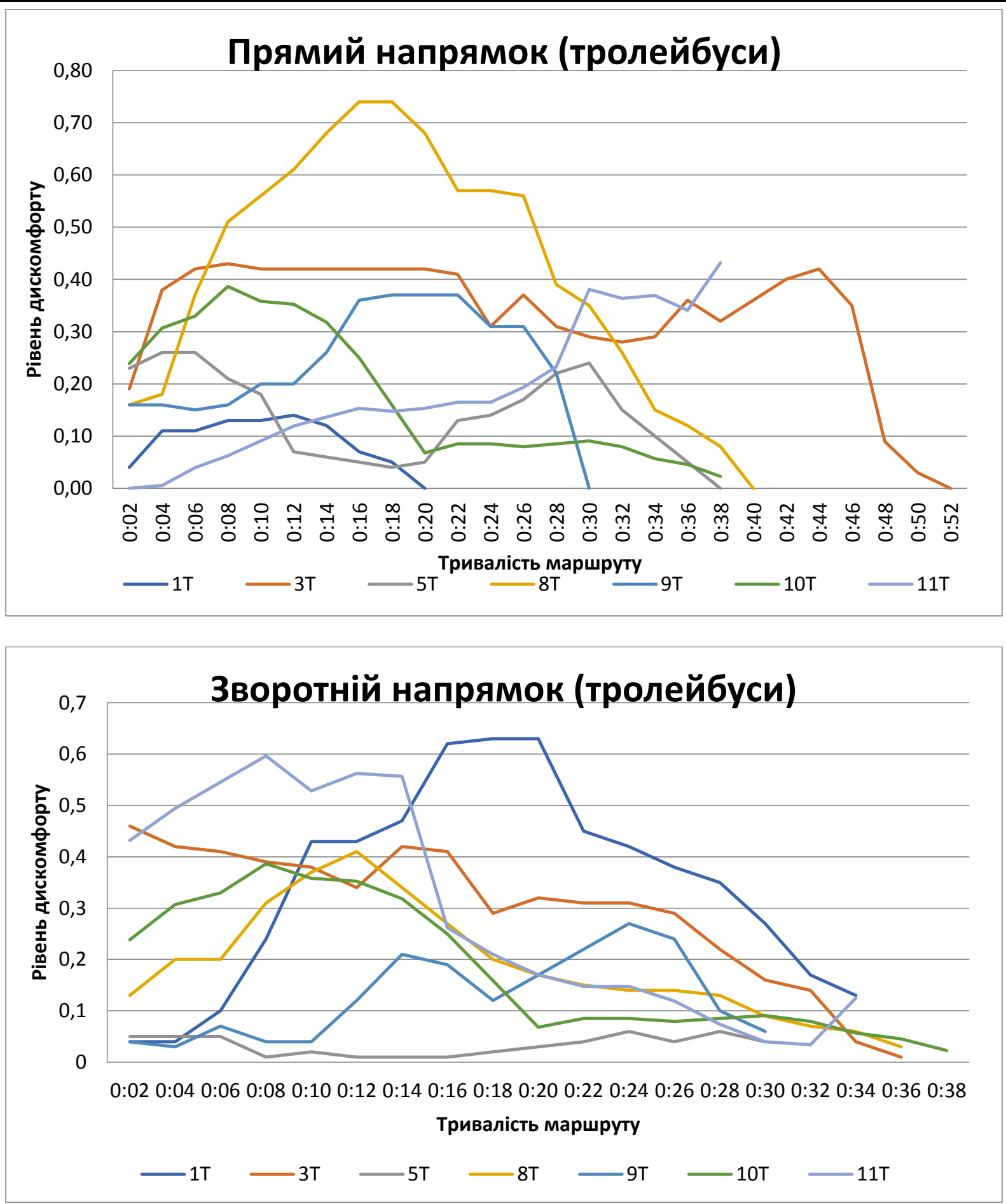

б)

Рисунок 4. Загальний рівень дискомфорту як функція щільності пасажирів за часом у поїздці маршрутом громадського пасажирського транспорту: а) автобусні маршрути; б) тролейбусні маршрути

При реалізації (1), (2), на рис. 4 представлено графічне зображення загального рівня дискомфорту як функції щільності пасажирів в транспортному засобі в часі поїздки дослідженими маршрутами вказаного виду транспорту для прямої та зворотньої поїздок.

Для подальшого оцінювання дискомфорту рекомендовано відомий methods for determining the importance weigh, функція набуватиме кусково-лінійної форми, рівень сумарного дискомфорту пасажирів що знаходяться в салоні транспортного засобу в процесі транспортування [11]

$$
f\left(x_{t}\right)=\sum_{i} w_{i} \cdot x_{i t}
$$


де $x_{i t}$ - значення $i$-го визначника дискомфорту в $t$-й відлік часу, $w_{i}$ - величина $i$-го вагового коефіцієнта, $x_{i t}$ обчислюється з (1).

При формуванні вагових коефіцієнтів важливості автори статті вважають, що ваговий коефіцієнт для безпеки при перевезеннях в умовах пандемії COVID-19 не є прийнятним для оцінювання дискомфорту згідно (3) з тієї причини, що він є домінантою при прийнятті рішення пасажиром до початку поїздки “або - або”: їхати, чи не їхати даним транспотним засобом. За даними обліковців, якими проведено опитування у м. Тернополі, встановлено, що важливим при виборі пасажиром транспортного засобу, а також маршруту з можливих, $\epsilon$ показник комфорту від сидіння, їхати стоячи у салоні опитані пасажири бажали менше. 3 урахуванням даних опитування, а також даних досліджень Şükrü İmre and Dilay Çelebi для нас прийнято значення Seat comfort 0.0556, що, очевидно, корелює з Seat comfort 0.0615 для Т1 та Seat comfort 0.0762 для M2 [11]. Отже, значення вагових коефіцієнтів важливості: crowdedness in-vehicle 0.4053; air-temoerature in vehicle 0.2243; seat comfort 0.0556 information and guidance 0.0590 ; cleaning in vehicle 0.1324 ; physical condition 0.0899 ; vehicle breakdown 0.0335 [11]. Компонентний аналіз рівня дискомфорту відповідно маршрутів мережі громадського пасажирського транспорту [19, 20, 21,22] проведений для маршрутів на яких встановлене умовне порогове значення - одиниця - було перевищене (рис. 4): 1А, 8, 18, 22.

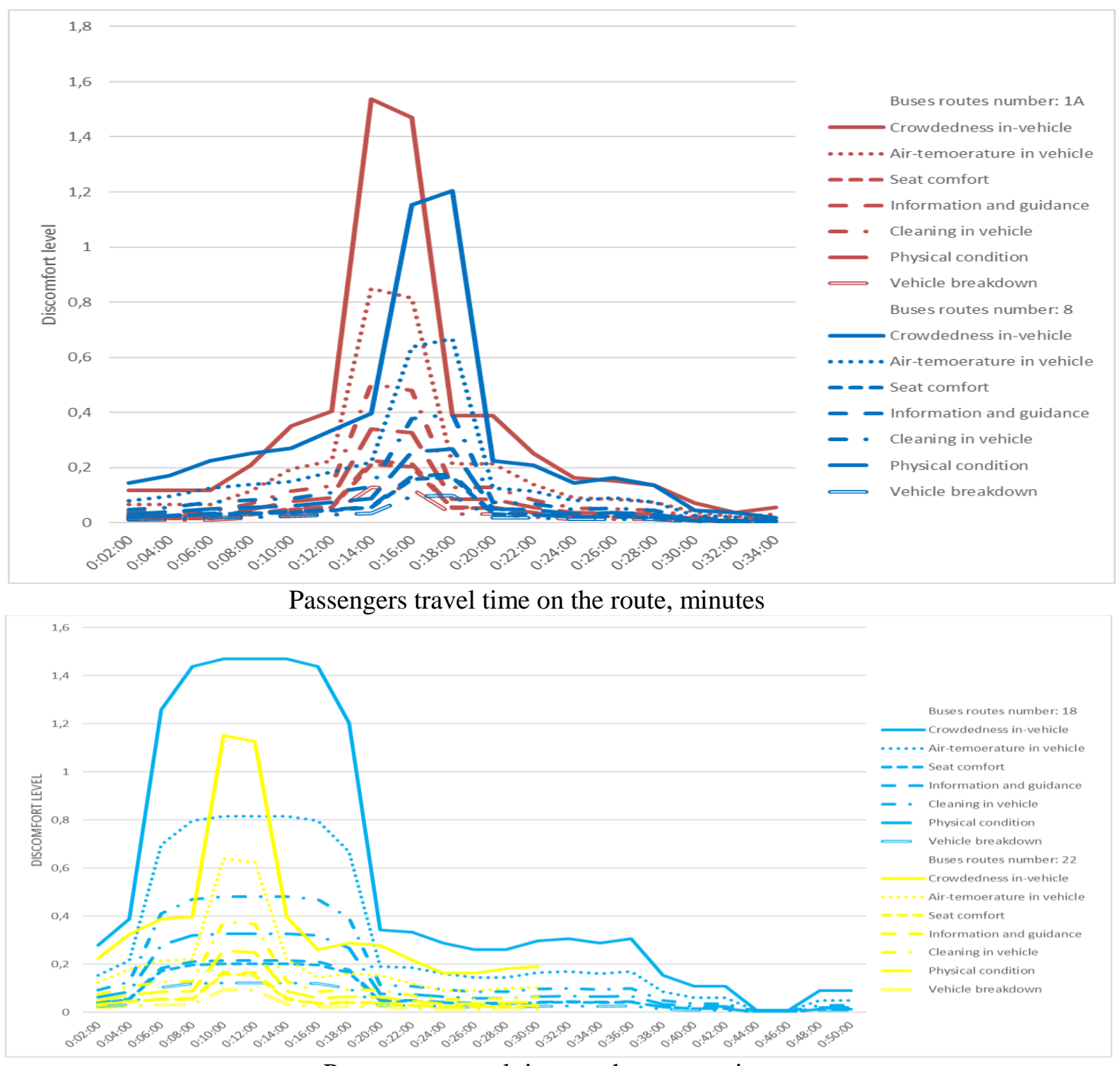

Passengers travel time on the route, minutes 


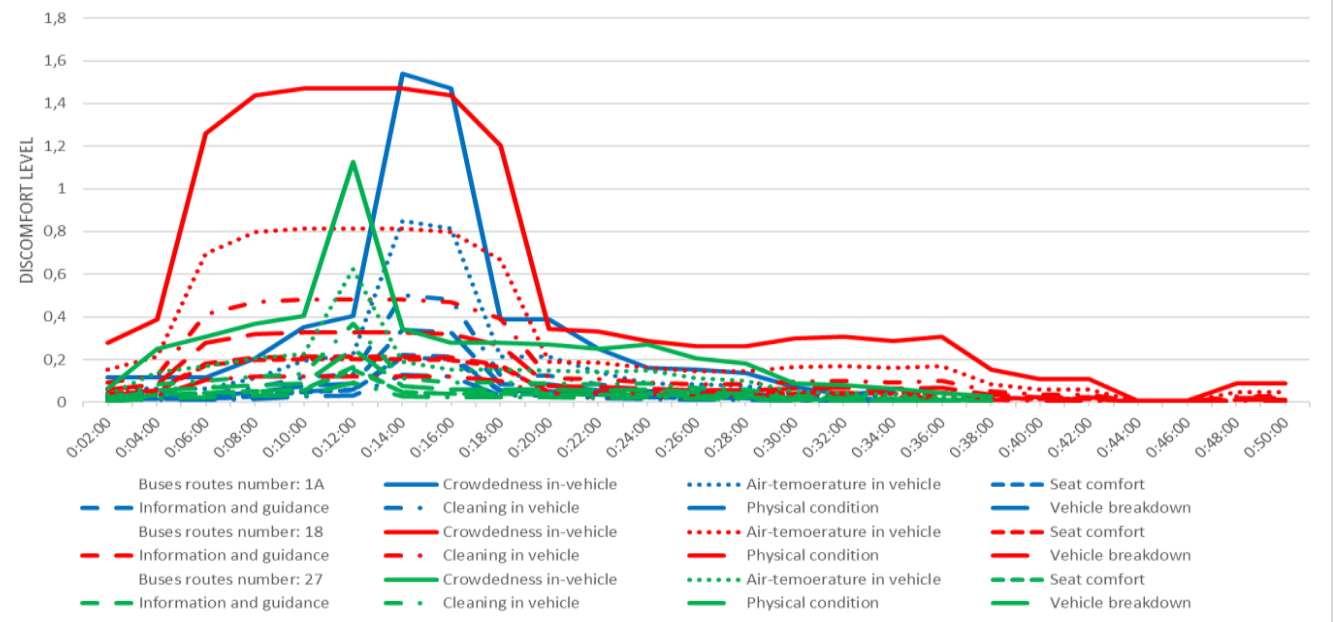

Passengers travel time on the route, minutes

Рисунок 5. Компонентний аналіз рівня дискомфорту за часом у поїздці маршрутом громадського пасажирського транспорту: а) прямі маршрути; б) зворотні маршрути

При реалізації (3), рис. 5, компонентним аналізом досліджено функції дискомфорту в часі поїздки дослідженими маршрутами вказаного виду транспорту для прямої та зворотної поїздок. Функції рівнів дискомфорту під час типових поїздок наведені на рисунках 4 та 5. Як видно з графіків, кількісні показники за величиною дискомфорту змінюються найбільше у залежності від crowdedness in-vehicle, air-temoerature in vehicle та seat comfort корелюючи та не змінюючись за тривалістю поїздки пасажрів. Також при плануванні міських пасажирських перевезень після завершення пандемії доцільно врахувати факт, встановлений дослідженням [18]: in transport planning, travel time to work is traditionally considered as a waste that should be minimized - fast and efficient transport remains the ultimate goal of planners. While innovations like the hyperloop and driverless vehicles promise everincreasing frictionless travel, more and more academic research has challenged this perspective and highlighted the intrinsic value of mobility [18]. Our survey provides further confirmation of the intrinsic value of mobility: $69 \%$ of respondents stated they miss at least some aspects of commuting. The main aspects missed by respondents include the activity of commuting itself (53\%), the ability to spend some time alone (25\%), and feeling independent (24\%) [18]. Отже, попит на пасажирські перевезення громадським транспортом значних змін не матиме.

Hu Shixiong, the lead author of the study who works for the Hunan Provincial Centre for Diseases Control and Prevention, стверджує [2], що кадри з відеокамер, якими було обладнано всі автобуси, надали можливість проведення оцінки дослідниками шляху поширення вірусу при виконанні перевезень пасажирів в салоні автобуса при закритих вікнах. Було встановлено, що хворий пасажир (рис. 6, фігура червоного кольору) не мав ніякого спілкування з іншими протягом чотирьох годинної поїздки. В автобусі пасажиромісткістю 48 місць для сидіння були зачинені всі вікна і працювала закрита система обігріву [2].

\section{How Covid-19 spread through a Hunan bus}

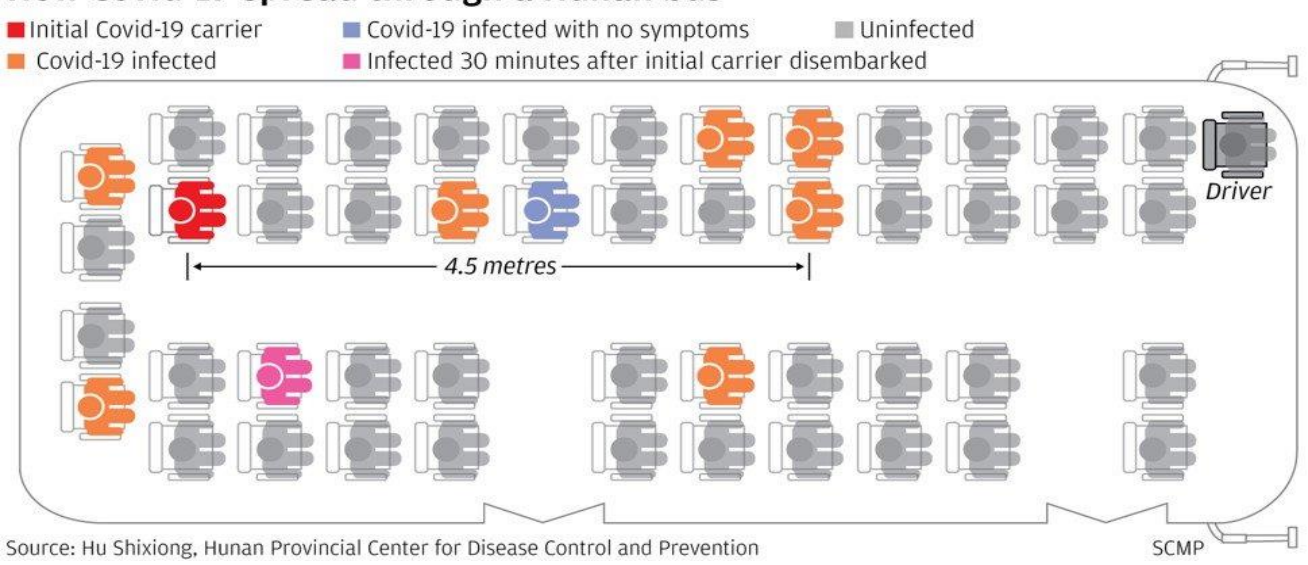

Рисунок 6. Схема поширення SARS-CoV2, [2] 
Дослідженням [2] визначено, що до того моменту, коли автобус зупинився на наступній зупинці, вірусом було вражено сім інших пасажирів, характерною особливістю є, що зараженими були не тільки люди, що сиділи відносно близько до хворого, але й інші, що знаходилися на відстані від 0 до 4,5 метрів від нього, хоча загальновідомим і доведеним вважається, що передача COVID-19 у повітрі на такі відстані $€$ обмеженою, оскільки крихітні крапельки вологи від подиху, які виробляються враженими людьми швидко опускаються вниз (рис. 4, фігури жовтого кольору) [2]. Переважна більшість пасажирів (сірий колір) не інфікувалися, навіть ті, які сиділи поруч з хворим. Приблизно через 30 хвилин у зворотному напрямку цим же автобусом їхали інші пасажири один 3 яких, що сидів у першому ряду з протилежної сторони проходу був заражений. Стверджується [2], що можливою причиною було вдихання людиною без захисної маски аерозолі з повітря, надиханого зараженими пасажирами з попередньої поїздки, в повністю закритому просторі повітряний потік в основному рухається за рахунок теплого повітря від працюючого кондиціонера, таким чином рух гарячого повітря може транспортувати краплі вірусу на відстань до 4,5 метрів. Також вказаними дослідженнями встановлено [2], що перший заражений пасажир вийшовши 3 маршрутного автобуса, сів на інший автобус у якому здійснив наступну поїздку протягом однієї години у результаті чого COVID-19 2 вразив ще двох інших пасажирів, причому один з них також знаходився на відстані 4,5 метри від зараженого, на момент закінчення дослідження хворий заразив 13 пасажирів, доведено, пасажири, які сидять безпосередньо біля перевізників SARS-CoV2, з невстановлених причин не були заражені, хоча, очевидно, вони зазнавали найбільшого впливу аерозолів з COVID-19. Дослідженнями доведено, ніхто з пасажирів, що носили маски, у двох автобусах, не був зараженим, SARS-CoV2 може перебувати у повітрі до 30 хвилин переміщуючись 3 повітрям до 4,5 метрів що $є$ далі, ніж "безпечна відстань яку рекомендує ВООЗ - 1.8 метра" [2, 8].

\section{ВИСНОВКИ}

Потреба в мобільності населення міста є однією з базових потреб, яку необхідно задовольнити. В умовах пандемії, спричиненої COVID-19 виникають значні об'єктивні ускладнення з точки зору забезпечення максимально високого рівня безпеки пасажирів і водія при додержанні задовільного рівня комфорту. Результати проведених натурних досліджень з використанням моделі дискомфорту дозволяють коректно прогнозувати вибір виду транспорту і поведінку пасажирів при користуванні громадським транспортом, зокрема у містах середньої величини. Раціональним рішенням є адаптація технології перевезень до умов пандемії COVID-19 шляхом розробки динамічної політики швидкого реагування при транспортуванні людей конкретно для вказаної надзвичайної ситуації з зменшенням ризиків для пасажирів і водіїв, а не повне чи часткове, як у деяких країнах, закриття громадського транспорту. Враховуючи встановлені шляхом мультикретеріального аналізу транспортної мережі характерні для середніх міст показники перевезень людей у громадах - рівень дискомфорту, коефіцієнт пересадочності, коефіцієнт заповнення транспортного засобу, середній час перевезення, середню відстань перевезення, максимальне купіювання розповсюдження COVID-19 можна забезпечити формуванням адекватної до ситуації стратегії перевезення пасажирів. Необхідним $є$ при пасажирських перевезеннях дотримуватись заповнення салону автобуса винятково відповідно до передбачених конструкцію транспортного засобу сидячих місць максимальної кількості пасажирів, як доведено дослідженнями, штучне недовантаження транспортного засобу для уникнення щільного контакту пасажирів не впливає рівень зараження COVID-19 і тому дане обмеження не $\epsilon$ доцільним. Обов'язковим $є$ використання таких засобів захисту як маски та рукавиці, посилена вентиляція салону, а також організація посадки - висадки пасажирів для максимального захисту водія тільки на задні двері з обов'язковою 100\% безконтактною оплатою проїзду, що реально забезпечить високий рівень захисту пасажирів.

1.https://nacto.org/program/covid19/

\section{ПЕРЕЛІК ДЖЕРЕЛ ПОСИЛАННЯ}

2.South China Porning print edition as: https://www.scmp.com/news/china/science/article/3074351/coronavirus-can-travel-twice-far-official-safedistance-and-

stay?fbclid=IwAR27JEyG3attieN4acGcevJLLtsmbYDY8Sz68HbzPHMV5MIWeHTCjDMqRpQ

3.ДБН .2.2-12:2019 Планування та забудова територій: https://dbn.co.ua/pay/pub01/dbn-B-

2212_planuvannya.pdf

4.http://www.ukrstat.gov.ua/

5.https://businessforsmartcities.com/load/118/presentation/7_sergiy_nadal_6_852c9.pdf 
6.www.eway.in.ua

7.http://bus.ck.ua/

8.https://www.who.int/ru/emergencies/diseases/novel-coronavirus-2019/advice-for-public

9.Palma, A. d., Kilani, M., \& Proost, S. (2014). Discomfort in mass transit and its implication for scheduling and pricing. Transportation Research Part B , 1-18.

10.Qin, F. (2014). Investigating the In-Vehicle Crowding Cost Functions for Public Transit Modes. Hindawi Publishing Corporation Mathematical Problems in Engineering, 1-13.

11.Şükrü İmre and Dilay Çelebi. 2017. Measuring Comfort in Public Transport: A case study for Istanbul. Transportation Research Procedia 25 (2017), 2441-2449.

12.Popovych P, Lyashuk O, Shevchuk O, et al. Influence of organic operation environment on corrosion properties of metal structure materials of vehicles. INMATEH - Agric Eng. 2017;52(2):113-118.

13.Lytvynenko, I.V., Maruschak, P.O., Lupenko, Popovych P.V. Modeling of the Ordered Surface Topography of Statically Deformed Aluminum Alloy Mater Sci (2016) 52: 113.

14.Popovych, P., Shevchuk, O., Dzyura, V., Poberezhna, L., Dozorskyy, V., Hrytsanchuk, A., 2018. Assessment of the Influence of Corrosive Aggressive Cargo Transportation on Vehicle Reliability. International Journal of Engineering Research in Africa 38, 17-25. https://doi.org/10.4028/www.scientific.net/jera.38.17

15.B. Sokil, O. Lyashuk, M. Sokil, et.al "Dynamic Effect of Cushion Part of Wheeled Vehicles on Their Steerability", International Journal of Automotive and Mechanical Engineering, vol. 15, no. 1, pp. 4880-4892, 2018. doi: 10.15282/ijame.15.1.2018.1.0380

16.Sekulić, D., Dedović, V., Rusov, S., Obradović, A., Šalinić, S.: Definition and determination of the bus oscillatory comfort zones. Int. J. Ind. Ergon. 53, 328-339 (2016)

17.https://www.citylab.com/transportation/2020/05/commute-car-traffic-transit-bike-remote-workcoronavirus/611365/?fbclid=IwAR3Ykbyf9yWC9jJhI-

5tMk49jecimXa7zsOy1TgBUpBVUM1ZSXeHjNpMS_I

18.https://urbanstudies.uva.nl/content/blog-series/covid-19-pandemic-working-from-home-andcommuting.html?cb

19.Шевчук О. С. Порушення при облаштуванні паркувальних місць транспортних засобів на вулично-дорожній мережі міста// Сучасні технології в машинобудуванні та транспорті. - 2016. - No 1. - C. 167-171.

20.Шевчук О.С. Вплив показників ефективності на безпеку руху вулично-дорожними мережами/ О.С. Шевчук // Вісник ХНТУСГ. - Харків, 2016. - № 169. - С. 205- 209.

21.Попович П. В. Дослідження комфорту в громадському транспорті м. Тернополя / П. В. Попович, Л. Я. Побережний, І. С. Мурований, О. С. Шевчук, П. Б. Прогній, Я. Побережна Л., В. М. Плотиця // Сучасні технології в машинобудуванні та транспорті. - 2020. - № 2. - С. 88-98. -

22.Маяк М. М. Особливості розвитку ринку вантажних і пасажирських перевезень / М. М. Маяк, П. Б. Прогній, А. Й. Матвї̈шин, П. В. Попович, О. С. Шевчук, В. М. Островерхов, А. С. Коцур, О.В. Романишин // Сучасні технології в машинобудуванні та транспорті. - 2020. - № 2. - С. 64-71. Режим доступу: http://nbuv.gov.ua/UJRN/ctmbt_2020_2_10

\section{REFERENCES}

1. https://nacto.org/program/covid19/

2.South China Porning print edition as: https://www.scmp.com/news/china/science/article/3074351/coronavirus-can-travel-twice-far-official-safedistance-andstay?fbclid=IwAR27JEyG3attieN4acGcevJLLtsmbYDY8Sz68HbzPHMV5MIWeHTCjDMqRpQ

3.ДБН Б.2.2-12:2019 Планування та забудова територій: https://dbn.co.ua/pay/pub01/dbn-B2212_planuvannya.pdf

4.http://www.ukrstat.gov.ua/

5.https://businessforsmartcities.com/load/118/presentation/7_sergiy_nadal_6_852c9.pdf

6.www.eway.in.ua

7.http://bus.ck.ua/

8.https://www.who.int/ru/emergencies/diseases/novel-coronavirus-2019/advice-for-public

9.Palma, A. d., Kilani, M., \& Proost, S. (2014). Discomfort in mass transit and its implication for scheduling and pricing. Transportation Research Part B , 1-18. 
10.Qin, F. (2014). Investigating the In-Vehicle Crowding Cost Functions for Public Transit Modes. Hindawi Publishing Corporation Mathematical Problems in Engineering , 1-13.

11.Şükrü İmre and Dilay Çelebi. 2017. Measuring Comfort in Public Transport: A case study for Istanbul. Transportation Research Procedia 25 (2017), 2441-2449.

12.Popovych $\mathrm{P}$, Lyashuk $\mathrm{O}$, Shevchuk $\mathrm{O}$, et al. Influence of organic operation environment on corrosion properties of metal structure materials of vehicles. INMATEH - Agric Eng. 2017;52(2):113-118.

13.Lytvynenko, I.V., Maruschak, P.O., Lupenko, Popovych P.V. Modeling of the Ordered Surface Topography of Statically Deformed Aluminum Alloy Mater Sci (2016) 52: 113.

14.Popovych, P., Shevchuk, O., Dzyura, V., Poberezhna, L., Dozorskyy, V., Hrytsanchuk, A., 2018. Assessment of the Influence of Corrosive Aggressive Cargo Transportation on Vehicle Reliability. International Journal of Engineering Research in Africa 38, 17-25. https://doi.org/10.4028/www.scientific.net/jera.38.17

15.B. Sokil, O. Lyashuk, M. Sokil, et.al "Dynamic Effect of Cushion Part of Wheeled Vehicles on Their Steerability", International Journal of Automotive and Mechanical Engineering, vol. 15, no. 1, pp. 4880-4892, 2018. doi: 10.15282/ijame.15.1.2018.1.0380

16.Sekulić, D., Dedović, V., Rusov, S., Obradović, A., Šalinić, S.: Definition and determination of the bus oscillatory comfort zones. Int. J. Ind. Ergon. 53, 328-339 (2016)

17.https://www.citylab.com/transportation/2020/05/commute-car-traffic-transit-bike-remote-workcoronavirus/611365/?fbclid=IwAR3Ykbyf9yWC9jJhI-

5tMk49jecimXa7zsOy1TgBUpBVUM1ZSXeHjNpMS_I

18.https://urbanstudies.uva.nl/content/blog-series/covid-19-pandemic-working-from-home-andcommuting.html?cb

19.Shevchuk, O.S. (2016). Porushennya pry` oblashtuvanni parkuval’ny`x miscz` transportny`x zasobiv na vuly`chno-dorozhnij merezhi mista. Suchasni texnologiyi v mashy`nobuduvanni ta transporti, 1, $167-171$.

20.Shevchuk, O.S. (2016). Vplyv pokaznykiv efektyvnosti na bezpeku ruhu vulychno-dorozhnymy merezhamy. Visnyk HNTUSG, 169, 205-209.

21. Popovych P.V., Poberezhnyy L. YA., Murovanyy I.S., Shevchuk O.S., Prohniy P.B. Poberezhna L.YA, \& Plotytsya V.M. (2020) Doslidzhennya komfortu v hromads'komu transporti m. . Suchasni texnologiyi v mashy`nobuduvanni ta transporti, 2, 88-98.

22.M. Mayak M.M., Prohniy P.B., Matviyishyn A.Y., Popovych P.V., Shevchuk O.S., V.M. Ostroverkhov, Kotsur A.S. \& Romanyshyn O.V. (2020) Osoblyvosti rozvytku rynku vantazhnykh i pasazhyrs'kykh perevezen'. Suchasni texnologiyi v mashy`nobuduvanni ta transporti, 2, 64-71.

P. Prohnii, D. Popovych, O. Zakharchuk, O. Shevchuk, P. Popovych, I. Matvyeyeva, V. Ostroverkhov, A. Kotsur. Safety of passenger transportation in public transport inn a pandemic condition

In the conditions of the COVID-19 pandemic, there are significant objective problems in terms of safe transportation of the population by public transport. A dynamic policy of rapid response in the transportation of people to reduce the contamination risk of passengers and drivers is ensured by the fact that during transportation it is necessary to allow municipal authorities to transport people without burdensome restrictions on the number of passengers in the cabin, adhere to the level of cabin vehicle number seats of the maximum number of passengers. As it has been researched artificial underloading of a vehicle to avoid close contact with passengers does not affect the level of COVID-19 contamination, so this restriction is not rational, causing underloading and irrational significant financial losses of the carrier, resulting in likely dismissal of employees, respectively negative social effect. Recommendations have been made, such as the mandatory use of masks including gloves, increased ventilation of the cabin, as well as the organization of boarding - exit of passengers only through the rear door and $100 \%$ contactless fare payment for maximum driver protection. This study is the basis for the formation of public transport policy with regard to determine the level of safety in COVID-19 and passenger comfort with the development of basics for measuring the perception of the most important factors of public transport convenience, minimum discomfort and maximum safety.

Key words: organization of transportation, passenger safety, public transport, passenger traffic, route.

ПРОГНІЙ Павло Богданович, кандидат технічних наук, ст.викл. кафедри спеціалізованих комп'ютерних систем, Західноукраїнський національний університет, Тернопіль, Україна, e-mail: PPopovuch@gmail.com 
ПОПОВИЧ Данило Павлович, студент, гр.ММ-112, Тернопільський національний медичний університет, Тернопіль, Україна, e-mail: PPopovich@ukr.net

ЗАХАРЧУК Олена Павлівна, кандидат технічних наук, доцент, доцент кафедри транспорту і логістики, Західноукраїнський національний університет, Тернопіль, Україна, e-mail: olenaskyba8500@gmail.com. https://orcid.org/0000-0001-9452-9850

ШЕВЧУК Оксана Степанівна, кандидат технічних наук, доцент, доцент кафедри транспорту і логістики, Західноукраїнський національний університет, Тернопіль, Україна, e-mail: oksana_shevchuk84@ukr.net. https://orcid.org/0000-0001-8283-4620

ПОПОВИЧ Павло Васильович, доктор технічних наук, професор, професор кафедри транспорту i логістики, Західноукраїнський національний університет, Тернопіль, Україна, e-mail: PPopovich@ukr.net. https://orcid.org/0000-0001-5516-852X

МАТВССВА Ірина Валеріївна, доктор технічних наук, професор, професор кафедри екології, Національний авіаційний університет, Київ, Україна, e-mail: iryna.valeriivna.matvieieva@gmail.com https://orcid.org/0000-0002-8636-0538

ОСТРОВЕРХОВ Віктор Михайлович, кандидат економічних наук, доцент, доцент кафедри менеджменту, публічного управління та персоналу, Західноукраїнський національний університет, Тернопіль, Україна, e-mail: v.ostroverkhov@ wunu.edu.ua. http://orcid.org/0000-0002-3818-0604

КОЦУР Андрій Семенович, кандидат економічних наук, доцент, доцент кафедри менеджменту, публічного управління та персоналу, Західноукраїнський національний університет, Тернопіль, Україна, e-mail: a.kotsur@wunu.edu.ua. http://orcid.org/0000-0001-6986-4665

Pavlo PROHNII, Doctor of Philosophy, Senior Lecturer of Specialized Computer Systems department, West Ukrainian National University, Ternopil, Ukraine, e-mail: PPopovuch@gmail.com

Danylo POPOVYCH, student, gr.MM-112, I. Horbachevsky Ternopil National Medical University, Ternopil, Ukraine, e-mail: PPopovich@ukr.net

Olena ZAKHARCHUK, Doctor of Philosophy, Associate Professor of Transport and Logistics department, West Ukrainian National University, Ternopil, Ukraine, e-mail: olenaskyba8500@gmail.com. https://orcid.org/0000-0001-9452-9850

Oksana SHEVCHUK, Doctor of Philosophy, Associate Professor of Transport and Logistics department, West Ukrainian National University, Ternopil, Ukraine, e-mail: oksana_shevchuk84@ukr.net. https://orcid.org/0000-0001-8283-4620

Pavlo POPOVYCH, Doctor of Sciences, Professor, Professor of Transport and Logistics department, West Ukrainian National University, Ternopil, Ukraine, e-mail: PPopovich@ukr.net. https://orcid.org/00000001-5516-852X

Iryna MATVYEYEVA, Doctor of Sciences, Professor, Professor of Department of Ecology, National aviation university, Kiev, Ukraine, e-mail: iryna.valeriivna.matvieieva@gmail.com https://orcid.org/00000002-8636-0538

Viktor OSTROVERKHOV, Doctor of Philosophy, Associate Professor, Associate Professor of Department of Management, Public Administration and Personnel, West Ukrainian National University, Ternopil, Ukraine, e-mail: v.ostroverkhov@wunu.edu.ua. http://orcid.org/0000-0002-3818-0604

Andriy KOTSUR, Doctor of Philosophy, Associate Professor, Associate Professor of Department of Management, Public Administration and Personnel, West Ukrainian National University, Ternopil, Ukraine, e-mail: a.kotsur@wunu.edu.ua. http://orcid.org/0000-0001-6986-4665

DOI 10.36910/automash.v1i16.514 